Journal of Southeast Asian Studies, 40(3), pp 593-612 October 2009. Printed in the United Kingdom.

(c) 2009 The National University of Singapore doi:10.1017/S0022463409990087

\title{
Common ground: Race and the colonial universe in British Malaya
}

\author{
Sandra Khor Manickam
}

This article explores the common bases of knowledge on race among Malay intellectuals and British scholar-officials in British Malaya. It focuses on genealogies of knowledge that not only lead back to Europe, but to contexts in the Malay Archipelago, encompassing both coloniser and colonised as agents of production of colonial knowledge on race. Race was a strategy adopted by Malay intellectuals in a colonial milieu, in line with histories and conditions before and during the period of British control over Malaya. The notion of complicities is explored in studying the interaction between British and Malay intellectuals which produced colonial knowledge on race.

This paper deals with the history of knowledge formed in or influenced by a colonial setting, in particular the history of ideas of race in colonial British Malaya. Using the case of colonial Malaya, and exploring the history of race ideas by Malay intellectuals and British colonial administrators, I seek to question the history of what can be termed 'colonial knowledge' on race and, in particular, to ask whose knowledge it is. The impetus for asking this question is to inquire in what ways colonial knowledge was not only formed by the coloniser, but also involved the colonised, not merely as subjects of that knowledge but as practitioners, innovators, developers and perpetrators. This line of argument follows from calls by scholars such as Bernard Cohn, Ann Stoler and Frederick Cooper to put the coloniser and the colonised in the same frame of study, and to question the bases and workings of colonial knowledge. ${ }^{1}$

Another reason for asking whose knowledge colonial knowledge on race belongs to is to question two basic assumptions of race knowledge. Authors such as Lim Teck Ghee and Colin Abraham focus on race as an unfortunate 'hand-me-down' from Malaysia's British colonial past that was perpetuated by colonial officers and

Sandra Khor Manickam is a Ph.D. candidate at the Department of Pacific and Asian History, Research School of Pacific and Asian Studies, the Australian National University. Correspondence in connection with this paper should be addressed to: sandra.manickam@anu.edu.au. She is currently researching the history of British anthropological scholarship on Malaya. The author wishes to thank Ingrid Maria Hoofd and two anonymous referees for their helpful comments and suggestions.

1 Bernard S. Cohn, Colonialism and its forms of knowledge: The British in India (Princeton: Princeton University Press, 1996); Ann Laura Stoler and Frederick Cooper, 'Between metropole and colony: Rethinking a research agenda', in Tensions of empire: Colonial cultures in a bourgeois world, ed. Frederick Cooper and Ann Laura Stoler (Berkeley: University of California Press, 1997), pp. 1-56. 
institutions. $^{2}$ This basis of Malaysian history seems to be taken as a given. The second assumption comes from works on colonial situations in general that trace race back to colonial powers in attempts to show that the colonised were oppressed. Both arguments suggest that race is typically a Western construct with a Western history which was imposed on colonised peoples. While not denying or eliding the coerciveness of institutions of rule in British Malaya which spread the idea of race, this article breaks down this opposition between race as owned by colonisers and race as transferred to the colonised, and complicates a simplistic characterisation of colonised peoples as victims. I do so by looking at the complicities between the two groups and by not assuming that race was only an imposition or that agency of colonised peoples did not play a role. I hope not only to expand the framework of race knowledge so that it involves a genealogy that leads back to Europe, but also to trace driving forces from within the Malay Archipelago. In studying the writings of Malay intellectuals in colonial Malaya as part of the production of knowledge on race, I am building on the work of Anthony Milner, who deals with the emergence of race as an ideological vehicle in relation to the emergence of a discourse of politics in Malaya. ${ }^{3}$ This article hopes to contribute to this discussion of the use of race by Malay authors through a closer comparison between racial theories espoused by a few prominent Malay intellectuals and those of British scholars. The implications of this comparison for understandings of colonial knowledge will be drawn out in the process of doing so. Through such an analysis, it will become clear that the 'adoption' of race knowledge in British Malaya occurred not because local actors were clean slates waiting to be written upon, but because it was a strategy taken to engage with the exigencies of their time and fitting with local histories.

In trying to map intersections in race knowledge, difficulties crop up due to the use of different languages to express that knowledge: English for British scholarofficials, and Malay, sometimes English, for Malay intellectuals. What were comparable terms for the English 'race' in Malay? In his book, The invention of politics in colonial Malaya, Milner discusses the nuances of various emotive group terms from writings in Malay ranging from Abdullah bin Abdul Kadir, a prominent teacher of Malay, in the first half of the nineteenth century to the nationalist Ibrahim Yaacob in the twentieth century. He focuses on 'bangsa' as the near equivalent of 'race' in the sense that it describes the group identification of Malays and subdivisions among people, a definition also used by Virginia Hooker. Yet, 'bangsa' is not the only word that expresses the exclusiveness of Malays or the sense of a common ancestry. For instance, using the simple term 'orang' or simply 'Melayu' may be just as powerful as using 'bangsa'. John Crawfurd in the nineteenth century and later scholars Barbara and Leonard Andaya translate 'orang' as the generic term 'people'. However, when combined with 'Melayu' or other group names such as Bugis or Minangkabau, 'orang' may connote a racialised grouping of people. ${ }^{4}$

2 Lim Teck Ghee, 'British colonial administration and the "ethnic division of labour" in Malaya', Kajian Malaysia, 2, 2 (1984): 28-66; Colin E.R. Abraham, 'Racial and ethnic manipulation in colonial Malaya', Ethnic and racial studies, 6, 1 (1983): 18-32.

3 Anthony C. Milner, The invention of politics in colonial Malaya: Contesting nationalism and the expansion of the public sphere (Cambridge: Cambridge University Press, 1995).

4 Milner, Invention of politics in colonial Malaya, p. 52; Virginia Matheson Hooker, Writing a new society: Social change through the novel in Malay (Australia: Allen \& Unwin, 2000), p. x; John 
Some of these difficulties of commensurability are eased when race is approached as a strategy and not as a category with fixed boundaries. Race categories and identities can be understood as being forged among other perceived groups and identities, and as historically changing. ${ }^{5}$ While racial categories and attributes can be viewed as one of the strategies of British colonial rule in Malaya, it could also be said that race was a strategy for the colonised and, for the purposes of this study, particularly the Malay-identified colonised intellectual. ${ }^{6}$ The strategy of race, in terms of placing oneself within a particular racial group, identifying or creating its boundaries, or infusing that racial group with particular attributes, is itself a part of colonial knowledge on race. It interacted with government race categories as well as rhetorical and textual forms of race knowledge which were distributed through the writings of British scholar-officials. The intersections between the strategies of race of both coloniser and colonised were crucial in the formation of a Malay-identified community and in the use of that community by those intellectuals to effectively argue for a privileged position for Malays based in Malaya. Their discourse of race also has divergences from understandings of race held by the British, showing that there was not a wholesale and mindless adoption of race ideas.

\section{The state of colonial knowledge on race in late nineteenth-century Malaya}

In order to fully compare Malay genealogies to British ones, it is useful to map out their initial separate strands. By the late nineteenth century, at least two trajectories of race knowledge in Malaya came in contact with one another. In court texts written in Malay prior to this period, there were mentions of 'Melayu' and 'bangsa'. However, the meanings of these terms did not coincide with a far-reaching group of people across the whole of the Malay Peninsula and parts of the archipelago. 'Melayu' and 'bangsa' generally meant those of royal descent from Sumatra, as Matheson states. In other texts, Malay-ness was tied to cultural codes. In Tuhfat al-Nafis, a court text written in the 1860s, to be Melayu conferred power on the Bugis court, and qualifications of Malay-ness in the sense of certain attributes and codes of conduct were used to discriminate against those seen as threatening the stability of the court and the Bugis presence in the sultanate. ${ }^{7}$ Elsewhere, Milner argues

Crawfurd, A descriptive dictionary of the Indian islands \& adjacent countries, with an introduction by M. C. Ricklefs (Kuala Lumpur: Oxford University Press, 1971), p. 314; Barbara Watson Andaya and Leonard Y. Andaya, A history of Malaysia (London: Macmillan, 1982), p. 334.

5 This discussion is based on my reading of the works of Fredrik Barth, 'Introduction', in Ethnic groups and boundaries: The social organization of cultural difference, ed. Fredrik Barth (London: George Allen \& Unwin, 1970), pp. 9-38; and Anthony P. Cohen, 'Introduction: Discriminating relations - identity, boundary and authenticity', in Signifying identities: Anthropological perspectives on boundaries and contested values, ed. Anthony Cohen (London: Routledge, 2000), pp. 1-14.

6 My use of the phrase 'Malay-identified' is deliberately ambiguous. Some intellectuals may not be thought of as Malay by their peers or even present-day scholars, depending on the definitions of what constitute someone as Malay, or what the concept of 'Malay-ness' stands for. The term 'Malay-ness' captures the shifting boundaries of what is supposedly a well-defined group. It refers to the criteria and characteristics of being Malay, howsoever those are determined, either by those who identify themselves as Malay and as belonging to this group or by those who are not of this group and pose an outsiders' identification. See Contesting Malayness: Malay identity across boundaries, ed. Timothy P. Barnard (Singapore: Singapore University Press, 2004).

7 Virginia Matheson, 'Concepts of Malay ethos in indigenous Malay writings', Journal of Southeast Asian Studies, 10, 2 (1979): 351-71. 
that a pivotal point of a person's identity in the Malay Archipelago, just prior to or during the early period of British colonial rule, was the sultan. People identified themselves based on the sultan of their particular state and would recognise themselves as subjects of a sultan and not necessarily as members of a racial group. ${ }^{8}$

It is evident from reading the vernacular press of the late nineteenth and early twentieth centuries that organising people based on race became increasingly important and that there was a gulf between the preoccupations of the vernacular press with race and those of the court texts with the sultan. ${ }^{9}$ Though it is difficult to account for this difference in rhetoric, certain situations hint at why such an application of race was gaining currency in the Malay Peninsula. The printing press gave opportunities to people to voice allegiances to entities other than the courts. A printing press was first introduced to the archipelago in the seventeenth century by the Dutch, with a press arriving in the peninsula in $1806 .{ }^{10}$ Ian Proudfoot writes that 'the psychological potency of the new medium should not be underestimated'. Reading created 'a new kind of social relationship which depended not upon personal networks or neighbourhood obligations but upon the shared interests of individual subscribers'. ${ }^{11}$ As outlined by Benedict Anderson, this new medium of writing and communication fostered by groups outside of the courts enabled people to express issues that were distinct from those found in the court manuscripts. ${ }^{12}$

The second situation which may have helped the spread of race as an identity is the cosmopolitan environment in which printing took place. Printing during this time lay in the hands of three groups: the Europeans; the Muslim communities such as Malays, Javanese and Jawi Peranakan; and the Chinese Peranakan. ${ }^{13}$ European materials often tried to convert their readers to Christianity and to educate those enrolled in schools. Newspapers in Jawi (Malay in Arabic script) or Rumi (Malay in Romanised script) catered to literate Jawi Peranakan, Arabs, Malays and

8 Milner, Invention of politics in colonial Malaya, pp. 16-7. Patrick Sullivan, however, contends that though the text would have the reader believe that the raja constituted the focal point of a person's identity, this could be far from actual experience; see Patrick Sullivan, 'A critical appraisal of historians of Malaya: The theory of society implicit in their work', in Southeast Asia: Essays in the political economy of structural change, ed. R. Higott and R. Robison (London: Routledge and Kegan Paul, 1985), p. 67.

9 Some of the usages of 'Melayu' and 'bangsa' in court texts do approximate the meanings in the press. For instance, Matheson notes that in Misa Melayu, 'bangsa' in some places in the text distinguished different groups of people from different parts of the archipelago, while in other places it strictly denoted status. The latter meaning, however, was more common in the court texts (Matheson, 'Concepts of Malay ethos', p. 366).

10 A. Wahab Ali, The emergence of the novel in modern Indonesia and Malaysian literature: A comparative study (Kuala Lumpur: Dewan Bahasa dan Pustaka, 1991), pp. 49, 60.

11 Ian Proudfoot, 'New technologies and new perspectives', in Early modern history, ed. Anthony Reid (Singapore: Archipelago Press, 1999), p. 129.

12 Benedict Anderson, Imagined communities: Reflections on the origins and the spread of nationalism (London: Verso, 1991).

13 Jawi Peranakan referred to those who had Indian and Malay ancestry and who were Muslims, mostly the product of Indian-Muslim and Malay marriages in the 18th and 19th centuries. Chinese Peranakan (sometimes also referred to as Baba or Straits Chinese) were those who retained their Chinese identity and who had taken on aspects of Malay culture such as language and dress. This absorption of Malay culture was due to intermarriage between Malays and Chinese or merely long-standing ties to Malaya; Charles Hirschman, 'The making of race in colonial Malaya: Political economy and racial ideology', Sociological Forum, 1, 2 (1986): 338. 
Malay-speaking Chinese with reports on trade and entertainment. Most printed material, being expensive and scarce, did not cater to a broad section of society. Some texts were only accessible through colonial schools and literacy rates were very low outside of elite groups such as Europeans, Chinese Peranakan and a section of Malays located in the Straits Settlements and western Malay States, which sparked off keen competition for readership, often resulting in scathing editorials aimed at undermining rival newspapers' credentials. ${ }^{14}$

Under such circumstances, ideas of what constitutes a 'Malay' were used by some writers to build identities and to guard against perceived infringements on their place in Malaya. The embodiment of those threats was found in other Malays, Chinese, Indians and Europeans. The term 'Malay' was imbued with various connotations by newspaper writers, such that it was difficult to determine who was and was not Malay. A telling example of this can be found in a few of the newspaper debates of the late nineteenth century between publishers vying for a similar readership in Singapore and the Malay states. In 1894, a debate ensued between the newspapers Bintang Timor and Jawi Peranakan. The documented argument started when Bintang Timor published a series of articles under the heading of 'Mengapa Melayu layu?' (Why are Malays withering?) by an author known only by the pseudonym Senex. Bintang Timor was a Chinese Peranakan-run newspaper, edited by Song Ong Siang, a leading member of the community. The newspaper was published in Rumi Malay, which was not popular among many in the Malay-Muslim community. ${ }^{15}$ Jawi Peranakan did not appreciate the analysis of Malays in those articles and responded from the position of one part of a Malay community reluctant to let groups seen as outside of that community comment on its state of affairs. ${ }^{16}$

While this exchange may have seemed to be between two different groups or two 'races', it is unclear whether the author of 'Why are Malays withering?' was Malay and Muslim, even though he was assumed not to be by Jawi Peranakan. The matter is complicated further by an earlier exchange in 1888 between Jawi Peranakan and Sekola Melayu, where the latter newspaper addressed the authors of the former as non-Malays. Competition between these newspapers prompted a writer for Sekola Melayu to hurl insults at the writers of Jawi Peranakan, calling them 'peranakans from Bombay (India)... who do not know the ways of us Malays'. To draw further attention to Jawi Peranakan as not Malay, and not 'us', the Malay language used by Jawi Peranakan was criticised. Yet, the 'Malay' credentials of Sekola Melayu's writers were themselves assailable. Those known as Jawi Peranakan often intermarried with Malays, thereby assimilating certain aspects of Malay culture and regarding themselves as Malays. One of the writers of Sekola Melayu, Mohammed Alie, was of Indian origin and had written for Jawi Peranakan before starting Sekola Melayu. ${ }^{17}$

14 Ahmat Adam, Sejarah dan bibliografi akhbar dan majalah Melayu abad kesembilan belas (Bangi: Penerbit Universiti Kebangsaan Malaysia, 1994), pp. 45, 61-72; Proudfoot, 'New technologies and new perspectives', pp. 10-44; A. Wahab Ali, Emergence of the novel, p. 63.

15 Ahmat Adam, Sejarah dan bibliografi akhbar dan majalah Melayu, pp. 71-4.

16 William R. Roff, The origins of Malay nationalism (Kuala Lumpur: University of Malaya Press, 1967), pp. 54-5.

17 Ahmat Adam, Sejarah dan bibliografi akhbar dan majalah Melayu, pp. 61-3; Roff, Origins of Malay nationalism, pp. 48-9; Nik Ahmad Hassan, The Malay vernacular press (University of Malaya: Department of History, 1958), p. 3. 
It is clear that contestations surrounding who was Malay were already present in the late nineteenth century and that different strategies of race were used. To present oneself as Malay and to discredit the Malay-ness of others played a role in furthering the interests of those newspapers. Being Malay was imbued with a variety of characteristics involving changeable boundaries depending on who was speaking.

This history of Malay-ness in the archipelago, with the movement of the discourse of Malay-ness from court writings to the vernacular press, is in contrast to the history of race studies as developed by British colonial scholars during the same period. Knowledge production by British authors was closely tied to territorial acquisitions in the Malay Peninsula during the nineteenth century which saw the British government and Malay polities begin more extensive political relations than had hitherto been known. ${ }^{18}$ With the involvement of British traders and administrators in the peninsula came reports and scholarly works concerning the area. Trading records had previously been the main source of information regarding the peninsula but now British administrators and those sharing an interest in Malaya amassed knowledge for both administrative purposes and for interested British readers. This was part of a scientific endeavour to understand the region, and particularly the Malays, as a whole in a serious manner, which included organising people in racial hierarchies. ${ }^{19}$ News of people found in Southeast Asia travelled back to Europe. Archaic fields such as 'ethnology' which encompassed what is today anthropology, linguistics and history were fed on this information, with 'race' being a significant category of study. Race theories were used to explain differences among the groups of people found in this new territory, and between them and the ethnic groups found in Europe and other parts of the world. ${ }^{20}$

While categorising people into races and describing their attributes appeared to British scholars as the objective study of human beings, the reading of those peoples was of course coloured by assumptions regarding their place in a hierarchy of culture and civilisation and by the relationship between those peoples and British colonial endeavours in Southeast Asia. Many British authors had initially regarded all inhabitants of the Malay Archipelago as Malays, and considered only those east of the archipelago as a different group, the Papuans. This conflation of peoples in the archipelago is arguably due to the fact that Malay was the lingua franca of the peninsula and its neighbouring islands; it was thus the language commonly encountered by the British in the region, who then erroneously associated language usage with race. Although William Marsden tried to be more discerning, he still ended up with the limiting definition of Malays as those who spoke Malay and traced their origins to Sumatra. Stamford Raffles, however, asserted plainly that the Malays were spread far and wide in the archipelago. Different authors also placed the seat of the Malay race in

18 T.N. Harper, The end of empire and the making of Malaya (New York: Cambridge University Press, 1998), pp. 17-18.

19 Hendrik M.J. Maier, In the centre of authority: The Malay Hikayat Merong Mahawangsa (New York: Southeast Asia Program, Cornell University, 1988), pp. 38-9, 43.

20 There is a wealth of information available on the subject of the history of anthropology. See, for example, Martin S. Staum, Labeling people: French scholars on society, race, and empire 1815-1848 (Montreal: McGill-Queens University Press, 2003); Nancy Leys Stepan, Picturing tropical nature (London: Reaktion Books, 2001); and George W. Stocking Jr, Victorian anthropology (New York: Free Press, 1987). 
different parts, either in the Malay Peninsula as asserted by Crawfurd, or in Sumatra, as stated by Marsden. Crawfurd's hypothesis, however, carried more weight in the face of the Anglo-Dutch Treaty of 1824, which excluded the rest of the archipelago from possible British involvement and formed a neat separation between peoples found in the peninsula and those located in the rest of the archipelago. ${ }^{21}$

These two driving forces brought about discourses with varying trajectories, but which overlapped and intersected at various points. The introduction of the printing press by Europeans, the creation of a cosmopolitan environment centred in the Straits Settlements of the British colonial empire, and the concerns that came along with newspaper rivalry constituted the mix in which a discourse of Malay-ness emerged. The concern with issues such as one's place of birth, ancestry, ways of life and language demonstrated within the newspaper exchanges is similar to, yet not quite the same as, the European racial way of determining the place of human beings. Seemingly based in scholarly objectivity, the scrutiny paid to racial origins included assessments concerning civilisational status, ways of life and place of origin as a way of discriminating between people, thus forming similarities with the writings in Malay. Despite this partial convergence, Malay intellectuals' discussion of Malay-ness would change by incorporating and innovating on certain features of what is understood as British race discourse.

\section{Complicities in, or the production of, colonial knowledge}

British trajectories of race knowledge changed course during the consolidation of their power in the Malay Peninsula. By 1909, all the states in the peninsula were under British protection or advice. The first four states to come under British protection were federated into an administrative body in 1895, combining the governmental workings of separate states into one. In 1909, the northern Malay states came under British protection under an agreement between the British and Siamese governments. Lastly, during that same year, Johor formally accepted British advice. ${ }^{22}$ With this change in British position in the peninsula came changes in attitudes towards the kind of investigations that were deemed important and also towards the rhetoric surrounding Malays. As P.L. Burns wrote in his introduction to R.J. Wilkinson's Papers on Malay subjects, 'Unlike the preceding generation who were concerned with problems of establishing and sustaining British authority, this group - the second generation British officers - could afford to ... raise questions about the future development of the Malay States and especially about British policy towards the Malays.'23

Whereas initial attempts at describing Malay-ness had been mostly exploratory, influenced by the uncertain position of the British in Southeast Asia, subsequent

21 Anthony Reid, 'Understanding Melayu (Malay) as a source of diverse modern identities', in Contesting Malayness, ed. Barnard, pp. 1-24; Lady Sophia Raffles, Memoir of the life and public services of Sir Thomas Stamford Raffles (Singapore: Oxford University Press, 1991), p. 15; John Leyden's Malay annals, with an introductory essay by Virginia Matheson Hooker and M.B. Hooker, MBRAS Reprint 20 (Selangor: MBRAS, 2001), p. 46; Frank Swettenham, British Malaya: An account of the origin and progress of British influence in Malaya (London: J. Lane, Bodley Head, 1920), pp. 158-9.

22 Harper, End of empire and the making of Malaya, p. 18.

23 R.J. Wilkinson, Papers on Malay subjects, selected and introduced by P.L. Burns (Kuala Lumpur: Oxford University Press, 1971), p. 2. 
knowledge was formed during heavy colonial involvement in the affairs of the Malay states and its rapid economic progress. The various aspects of British racial construction of Malays under such conditions are well known. The stereotype of lazy Malays and hardworking Chinese served the purposes of the British who wanted to develop Malaya's economy using Chinese labour and at the same time, preserve Malays as they supposedly were. This position of stewardship was upheld by promoting the perceptions that Malays and Chinese could not coexist peacefully, and that Malays would be swamped economically and numerically by the Chinese if left to their own devices. The effect of this approach was the entrenchment of the position of the British as stewards over the Malays, and the rationale that it was Britain's duty to develop the economy and the natural resources of the country on behalf of the Malays, who were unable to do so themselves. Furthermore, the British continued to pose indigenousness as a racial issue. Being part of the Malay racial group (and their associated groups such as those from the archipelago) meant being indigenous to Malaya. By this formulation, other racial groups were unable to gain access to indigenousness and the rights that were associated with that state of being. ${ }^{24}$

These aspects of British race construction can be seen in the writings of Malays in the early part of the twentieth century. The first interpretation of this coincidence would be that the place given to race in Malay writings signals cooperation and a 'buying into' racial discourse by the colonised, what some would simplistically label as 'complicities'. There are several problems with this characterisation which hinge on issues of colonial coercion and local agency, as well as postcolonial heritage. Depending on which side of the fence one falls on, discourses of race could be seen as a curse, responsible for perpetuating tensions between races, or a blessing, giving people an identity or identities. If discourses of race are seen as a curse, the originator of that curse is oftentimes said to be the British during their rule of Malaya. However, the assumption that race was the 'fault' of the British may elide local agency in the adoption of race as an identity and as a strategy. Assigning responsibility to the British for perpetuating racial tensions is useful when wanting to show the impact of colonial rule and the coerciveness of imperialism; indeed, it is important to continue such analysis. In addition to this, there should be analysis into the process of syncretisation that occurred in a variety of cross-cultural encounters, of which colonialism was one. Issues of agency also crop up when genealogies of race which lead back to the British are drawn. While undoubtedly still upholding the view that colonialism was coercive, what kind of agency can be theorised in such an environment? Did agency disappear under coercion, or were there still ways of negotiation, and spaces where colonialism did not play its expected oppressive role?

24 Swettenham, British Malaya, pp. 133, 136, 147, 174; Syed Hussein Alatas, The myth of the lazy native: A study of the image of the Malays, Filipinos and Javanese from the 16th to the 20th century and its function in the ideology of colonial capitalism (London: Frank Cass, 1977), pp. 44, 70; Paul H. Kratoska, 'Proconsuls, yeoman and rice farmers: Cultural categories in British Malaya' (Ph.D. thesis, University of Chicago, 1975), p. 56; C.A. Vlieland, British Malaya (the colony of the Straits Settlements and the Malay States under British protection, namely the federated states of Perak, Selangor, Negri Sembilan and Pahang and the states of Johore, Kedah, Kelantan, Trengganu, Perlis and Brunei): A report on the 1931 census and on certain problems of vital statistics (London: Crown Agent for the Colonies, 1932), pp. $48,71,77-8$. 
Ideas of race can be conceptualised as both colonial and owned by Malay intellectuals, with 'colonial' meaning not just 'the West' or those in power, but also referring to a general universe born out of interactions between various parties in that setting. This history of race, which locates agency within Malay intellectual circles in colonial Malaya, shows the intersections between two genealogies of race knowledge which had similar interests and shared common ground. These intersections are hardly surprising given that the very separation between colonised and coloniser is sometimes unclear and that various actors within those two groups may have parallel interests in perpetuating certain forms of knowledge. Such a situation points to complicities between the two parties. While complicities may often carry the insinuation of 'sleeping with the enemy', the term also implies various layers of overlap between groups assumed to be on separate sides of the power structure. This describes aptly the interaction between Malay and British intellectuals on ideas of race. ${ }^{25}$

This knowledge of race among Malays coincided with some elements of British racial construction, but there were also key differences due to diverging strategies of race used by the Malays. Strategies are just that, courses of thought and action taken at particular times and places and ways of employing and deploying the discourses of race by some among the Malay intelligentsia. This is not to say that race was an all-encompassing preoccupation for these authors, or that it was always a dominant way of thinking. Indeed, there are other writings besides those studied in this article that focus on other aspects of knowledge and ways of being in Malaya. As an example, many Malay authors wrote on Islam and the ways of being a good Muslim. The issues they were concerned about were tied to developments in the Middle East and local factions of Islamic teaching within Malaya. ${ }^{26}$ Strategies of race do not imply exclusivity, in the sense that one strategy excluded using another or that strategies could not complement each other. In selecting the following texts, race is of course given emphasis as the strategy or identity that concerns this article, but it may not have been over-arching at the expense of other ways of being.

The three histories that illustrate a divergence from British race discourse and a movement towards a Malay-centred colonial discourse are Abdul-Hadi bin Haji Hasan's two-volume history entitled Sejarah alam Melayu (History of the Malay world), published in 1925; Abdul Majid Zainuddin's The Malays in Malaya, by one of them, written and published anonymously in 1928; and a series of translations by Zainal Abidin bin Haji Alhaj, or Za'ba, of writings by R.O. Winstedt, published in Majallah Guru from 1925 to $1929 .{ }^{27}$ Abdul-Hadi was a Malay writer from the Sultan Idris Training College (SITC) in Tanjung Malim, Perak. He wrote Sejarah

25 Ingrid Maria Hoofd, 'Feminist activism in the high-tech west: The complicities of transversal and networked politics in speed', in Gender and citizenship in a multicultural context, ed. Elzbieta Oleksy, Andrea Peto and Berteke Waaldijk (Berlin/Oxford: Peter Lang Verlag, 2008), pp. 19-35.

26 See chs. 6 and 7 in Milner's Invention of politics in colonial Malaya.

27 Abdul-Hadi bin Haji Hasan, Sejarah alam Melayu: Penggal I (Singapore: MPH Publications Sdn. Bhd., 1967); Abdul-Hadi bin Haji Hasan, Sejarah alam Melayu: Penggal II (Singapore: MPH Publications Sdn. Bhd., 1968); Anonymous, The Malays in Malaya, by one of them (Singapore: Printed at the Malaya Publishing House, Ltd., 1928); Sejarah ringkas Tanah Melayu, dikutip dan diterjemah dari bahagian2 yang menasabah dalam buku 'Malaya' karangan Dr R.O. Winstedt (yang telah terbit pada tahun 1922) oleh Za'ba dalam tahun 1925-26 (Singapore: Pustaka Melayu, 1961). 
alam Melayu for the Malay School Series, an initiative of the Malay Translation Bureau (MTB), with the approval of Winstedt, then Director of Education for the Federated Malay States and the Straits Settlements. Abdul-Hadi's history was used as material for the teacher training college. ${ }^{28}$ Abdul Majid wrote his book in response to L. Richmond Wheeler's The modern Malay published in the same year. He was a teacher who also wrote articles on Malay culture in the Journal of the Malayan Branch of the Royal Asiatic Society (JMBRAS). ${ }^{29}$ Za'ba began working as a translator and writer in the MTB under its founder O.T. Dussek in 1924. Za'ba was a main contributor to Majallah Guru, the magazine of the Malay Teachers Association of Singapore, Melaka and Negeri Sembilan. He became a significant figure in Malay literature and a prominent speaker on Malay issues. ${ }^{30}$

Merely looking at the credentials of these authors brings up a few common aspects: they were trained in institutions set up by the British colonial government, wrote under the auspices of colonial administrators, and/or used material from British authors on Malaya in their own writings. The two institutions that were instrumental in getting their works published and disseminated were the SITC and the MTB. Emblematic of the other training colleges in Melaka and Singapore, SITC was the place where a Malay intelligentsia rose and became vocal in the presses. These proponents of Malay nationalism set up newspapers and wrote articles, and in doing so shaped discourses surrounding the place of Malays in Malaya. Malay intellectuals also worked in other educational bodies such as MTB, which was responsible for the publication of Malay schoolbooks as well as works intended for a general readership. ${ }^{31}$ Institutions such as SITC and MTB were set up and run by the British. Intellectuals were 'produced' and 'trained' in those bodies by the British institutional heads, who instilled a sense of Malay-ness in their students and staff. William Roff notes that the head of SITC, Dussek, was concerned about Malays not taking their rightful place as the rulers of Malaya and communicated this concern to those around him. ${ }^{32}$ Curricula which emphasised the stereotypical literary heritage of Malays were set, and MTB published books which catered to such an idea. Together, SITC and MTB perpetuated a British racial discourse of Malays whose influences can be seen in the contents of the three histories.

28 Abdul-Hadi, Sejarah alam Melayu: Penggal I, iii; Abdullah Sanusi bin Ahmad, Peranan pejabat karang mengarang dalam bidang2 pelajaran sekolah2 Melayu dan kesusasteraan di-kalangan orang ramai (Kuala Lumpur: Dewan Bahasa dan Pustaka, Kementerian Pelajaran Malaysia, 1966), p. 99. Abdul-Hadi also taught Harun Aminurashid, who became a well-known author and proponent of Malay pride (Milner, Invention of politics in colonial Malaya, p. 273).

29 L. Richmond Wheeler, The modern Malay (London: George Allen \& Unwin Ltd., 1928); Abdul Majid Zainuddin, 'A peculiar custom in Kuala Kangsar', Journal of the Malayan Branch of the Royal Asiatic Society (hereafter JMBRAS), 3, 1 (1925): 85-6; Abdul Majid Zainuddin, 'A Malay's pilgrimage to Mecca', JMBRAS, 4, 2 (1926): 269-87. For more information on Abdul Majid Zainuddin's life, refer to his autobiography, The wandering thoughts of a dying man: The life and times of Haji Abdul Majid bin Zainuddin, ed. William R. Roff (Kuala Lumpur: Oxford University Press, 1978).

30 Abdullah Sanusi, Peranan pejabat karang mengarang, pp. 20-1; Hooker, Writing a new society, pp. 42, 101; Antologi esei Melayu dalam tahun2 1924-1941, ed. Zabedah Awang Ngah (Kuala Lumpur: Dewan Bahasa dan Pustaka, Kementerian Pelajaran, 1964), p. 209.

31 Wahab Ali, Emergence of the novel, pp. 65-8, 104-5; Abdullah Sanusi, Peranan pejabat karang mengarang dalam bidang2 pelajaran sekolah2, pp. 20-1; Roff, Origins of Malay nationalism, pp. $51 \mathrm{fn} .66$, $142,155-7$.

32 Roff, Origins of Malay nationalism, pp. 144-8; Hooker, Writing a new society, p. 76. 
If the analysis were to stop here, the histories would appear to have been borrowed directly from British racial discourses by virtue of using material written by colonial officers and getting approval for publication from British-run institutions. For instance, Za'ba's segmented history in Majallah Guru was taken from 'relevant' sections of Winstedt's edited volume, as his title suggests. ${ }^{33}$ Abdul-Hadi and Abdul Majid in their works drew frequently on the authority of British histories of Malaya and other established texts. The question arises as to whether there was any 'Malay' agency in the crafting of race discourses in those histories, and to what extent the authors 'merely' adopted British race ideas or were in agreement with them. It is reasonable to assume that texts produced with the blessing of colonial officers and under the auspices of colonial governmental bodies meant that they were in line with certain British ideologies, such as that of race ideology. If the choice of material translated implies anything, it is that to some extent the ideas present in those sections had affinities to the translator's own thinking, or were taken on by him. This observation may be applied to theories of racial origin and especially the emphasis given to Malays in the peninsula. However, the very act of translating only sections of the original text, and of recombining established texts and re-presenting them in another form and possibly to another audience, indicates that crafting took place in translating (as one can argue, it always does), similar to that of clear-cut authorship. It also suggests that the process of translating and reconstituting material may have entailed a divergence from the views present in those British texts.

A break can be discerned concerning those very elements of British race discourse which emphasised Malays' helplessness and the importance of Chinese, Indian and British institutions to Malaya. As was mentioned earlier, one major feature of British race discourse was the position of disempowerment of the Malays economically and politically, which carved a special place for the British to step in and play the role of protector and developer on their behalf. The way this ideology played out in several histories of Malaya during the early twentieth century gave the feeling of security and British ownership over Malaya, with Malays being important as the main 'natives', though ultimately not able or wanting to make themselves heard or felt, unlike Chinese and Indians. This can be seen in Winstedt's book on Malaya which Za'ba translated into Malay.

Malay strategies of race were far from fatalistic. Taking on racialised groupings instead of state-bounded or smaller group loyalties made it possible to talk of a unified Malay subject within the breadth of territory under British protection and rule. Such a subject projected into a community was then utilised to call for change regarding aspects of the conceived community, and to mould it in ways that were important to them. ${ }^{34}$ This can be seen in the wide prevalence of exhortation-type writings so common in the vernacular press and the moralistic short stories and poems written in Malay. These writings concentrated on the threat posed to Malays by Chinese and Indians, and the problem of Malays lagging behind in economic roles and the civil service in comparison to those groups. The racialising of a segment of the

33 My translation of Za'ba's title is, 'A short history of Malaya, selected and translated from relevant sections of "Malaya" written by Dr R.O. Winstedt (which was published in 1922)'.

34 Racial ideologies enabled the newspaper Utusan Melayu to extend its rhetoric as far as Ceylon (Milner, Invention of politics in colonial Malaya, p. 100). 
population enabled these writers to talk of Malays in relation to other groups less favoured by the writers, such as Chinese and Indians, and sometimes even the British. ${ }^{35}$

This could arguably be called a 'positive' use of racialisation, as opposed to the negative use by the British. The racialising of Malays, carried out through the study of ethnology (which later evolved into anthropology), produced knowledge that could be useful for the colonisation of Malaya and everyday governance. Studying Malay literature and language was believed to give a greater understanding of the people, as language was thought to be one of the keys to unravelling the types of man and the nature of a race. ${ }^{36}$ Administrators used their knowledge of the language to write formal letters to sultans and to draft treaties in Malay. The study of the Malay 'temperament', whether scholarly or superficial, was a subject of great interest in many a book introducing Malaya. Papers on Malay subjects, covering the living habits and culture of peninsular Malays, the history of the Malay states and Malay royalty is an instance of anthropological knowledge marshalled to serve the interests of a colonial government. Supplements were issued based on what additional information was seen as useful, for instance, a supplement on Aboriginal tribes. ${ }^{37}$ The weight of knowledge seemed to be on the side of the British in Malaya.

By turning these oftentimes stereotypical portrayals into elements which bound Malays together, the conceptual power of that knowledge entrenched them as the privileged race in the Malay Peninsula. All three histories homogenised Malays in Malaya, giving them historical and racial ownership. As noted earlier, Za'ba translated relevant portions of Winstedt's Malaya; portions selected, however, made all the difference in the tone of the translations. Consider that in Winstedt's book, the story of Malaya started out with a chapter entitled 'The Malay Peninsula: Its area, boundaries and editions, physical features and scenery', followed by chapters on climate, geology, minerals, flora and forests. While there were chapters devoted wholly or partially to Malays, at most they constituted only six out of 27 such chapters. Za'ba instead concentrated on chapters entitled 'The aboriginal and Malay races' and 'The history of the Malay Peninsula'. By doing so, Za'ba narrated a completely different story of Malaya from the profile provided by Winstedt, which portrayed it as a colony and protected states. ${ }^{38} \mathrm{He}$ transformed the story of a disempowered people into that of a community which assumed their rightful place as rulers of the peninsula, thus subtly questioning the British presence in Malaya but, more importantly, excluding migrant communities from such rights.

This is in contrast to the effects of writing histories of Malaya by the British, who instead took away questions of ownership. From the British perspective, the writing and dissemination of histories of Malaya filled several discursive roles. Histories of

35 Omar Mustaffa, 'Angan-angan dengan Gurindam', Utusan Melayu, 18 Jan. 1913, in Puisi-puisi kebangsaan 1913-1957, compiled by Abdul Latiff Abu Bakar (Kuala Lumpur: Dewan Bahasa dan Pustaka, 1987), p. 3; Mir Hamzah, 'Semenanjung...', Warta Ahad, 25 June 1939, in the same volume, p. 118; Roff, Origins of Malay nationalism, p. 151.

36 Stocking, Victorian anthropology, pp. 57-8.

37 Wilkinson, Papers on Malay subjects; R.J. Wilkinson, Papers on Malay subjects, supplement: The aboriginal tribes (Kuala Lumpur: Printed by J.E. Wallace at the F.M.S. Government Press, 1926). 38 Malaya, the Straits Settlements and the Federated and Unfederated Malay States, ed. Richard Winstedt (London: Constable, 1923). 
the various colonies or places under British protection/influence were put together to illustrate the extent of British power in the world, and Malaya was included in them even though not all of its states were outright colonies. Specific histories of Malaya were written as touristic pamphlets for those new to the place who may have been travelling for business or leisure, or transferred to Malaya as administrators. These histories gave an outline of what were considered to be the relevant points to note regarding Malaya, an introduction to 'our colonial possession'. ${ }^{39}$ The titles and headings of such books are telling: Winstedt's book had abundant information not only about the various peoples of Malaya, their roles and how they came to be in the Malay Peninsula, but also many chapters on the administration of and communications within Malaya, forestry and transportation. Winstedt gave an economic outline of development in Malaya and a depoliticised biography of the place, without an indication that British ownership over the colony was anything but outright.

The three histories, in contrasting ways, focused on a people, a race tied to Malaya, turning it into a vehicle for a variety of political ideologies and actions, and calling into question the totalising discourse of Malaya as a mere colonial possession. The narrative history performed this ideological twist in a number of ways. Za'ba wrote a history of a Malay people from its racial inception to its present condition in the geographical space of the peninsula, linking the race to the place. According to Za'ba's application of racial theories, Malays were a product of the mixture of peoples from the archipelago such as the Jakun, Sumatrans, Acehnese and Bugis (though not the most 'primitive' Negrito Semang). There was also a mixture of 'bangsa luar' (outside or foreign bangsa), such as Indian-Muslims. Yet, the Malays were now more undifferentiated due to the mixing of people within the peninsula, creating an essentialised Malay mass. ${ }^{40} \mathrm{Za}$ 'ba also linked Malays to the peninsula through a history of governance. His history of the Malay Peninsula took much from the history of the Melaka court and other neighbouring kingdoms. The effect of marrying the articles about the Malay race with these courts in the peninsula was to give the latter a racial slant as well: the link between subject and sultan was coloured by racial overtones. ${ }^{41}$ Thus, both the right to govern and the position of being governed within the peninsula were presented as an essentialised racial state of being which excluded the Chinese and Indians in particular.

As mentioned previously, the racialising of Malays through fields such as anthropology was used to serve the colonial administration. The relationship between the study of race and colonialism, however, was not a simple one. As much as British colonisation of Malaya influenced the anthropology of a Malay race, anthropology also fed back into colonialism. The very construction of Malays as a subject of

39 Arthur Berriedale Keith, The governments of the British empire (London: Macmillan and Co. Ltd., 1935); O.P. Austin, Colonial administration 1800-1900: Methods of government and development adopted by the principal colonizing nations in their control of tropical and other colonies and dependencies (Washington, DC: Government Printing Office, 1901); Arnold Wright and Thomas H. Reid, The Malay Peninsula: A record of the British progress in the Middle East (London: T. Fisher Unwin, 1912); Cuthbert Woodville Harrison, An illustrated guide to the Federated Malay States (1923), with an introduction by Paul Kratoska (Singapore: Oxford University Press, 1985); and Handbook to British Malaya 1929, compiled by R.L. German (London: Malayan Information Agency, 1929).

40 Sejarah ringkas Tanah Melayu, pp. 1, 9, 16-17, 28.

41 Ibid., p. 117. 
anthropology, just like the conceptualisation of the boundaries and provenance of the Malay race, was not 'natural' in the sense that it was easy to determine who was who. It can be argued that Malays could be thought of as a field of study and essentialised to a certain extent only by separating elements that were seen as incongruous with that race. Malays were stereotyped as 'peasants', 'Muslim' and 'kampung (village)-dwelling' natives, as opposed to the other natives who were 'wild', 'pagan' and 'forest-dwelling', characteristics that were embodied in indigenous peoples of the peninsula who were later grouped together and given the collective name 'Orang Asli' (original people).

British scholars expended much energy on trying to explain the presence of various lowland and hill tribes who seemed to have ways of life, cultures and religions very different from those who came to be termed wholly as 'Malays'. In their studies, these scholars noted though ultimately glossed over the overlap between the two groups: Malays who sometimes led tribal lives became or were related to Orang Asli and vice versa. It was common for British anthropologists to refer to Orang Asli as wild, uncivilised and savage with the authority of their field to back them up. Though Malays were sometimes 'degenerate', especially those who migrated to towns from kampung, they were still considered the closest local equivalent of the British gentleman. ${ }^{42}$

The ways that the three Malay authors rationalised Orang Asli were very similar to British anthropological writings. All three began their histories by giving an overview of the 'wild' or 'original peoples' of the Malay Peninsula who were said to be the first inhabitants before the appearance of Malays. Yet, the similarities with British scholars extended to the ways in which indigenous groups were analysed and catalogued. Abdul-Hadi and Za'ba used proof based on perceived physical characteristics to distinguish indigenous peoples. They were grouped into 'Semang' and 'Sakai', categorisation based on their physical stature, the colour of their skin, and the straightness or curliness of their hair. ${ }^{43}$ Abdul Majid, like many an anthropologist before and after him, put pictures of the 'typical' Orang Asli, a Sakai man, with his blowpipe in his book. ${ }^{44}$ Abdul-Hadi quoted from anthropologists W.W. Skeat and C.O. Blagden's work, reproducing their word-list comparison for a number of indigenous groups. Their material culture was judged to be primitive, and Orang Asli as a group were considered sorely lacking in civilisation. Abdul-Hadi was frank in his distaste for Orang Asli, saying that they were a stupid and frightening race, and that if Malays had been in the peninsula first they would have wiped Orang Asli out. Even Za'ba and Abdul Majid did not dispute the wild and primitive status of Orang Asli though they were more sympathetic to them. ${ }^{45}$

42 Wilkinson, Papers on Malay subjects, supplement: The aboriginal tribes, pp. 1-3; W.W. Skeat and C.O. Blagden, The pagan races of the Malay Peninsula (London: Macmillan, 1906), pp. xii, 16, 19; Nelson Annandale and Herbert C. Robinson, Fasciculi Malayenses: Anthropological and zoological results of an expedition to Perak and the Siamese Malay states, 1901-1902 (London: University Press of Liverpool, 1903), pp. 29-30; James de V. Allen, 'Two imperialists: A study of Sir Frank Swettenham and Sir Hugh Clifford', JMBRAS, 36 (1964): 46-7.

43 Abdul-Hadi, Sejarah alam Melayu: Penggal I, pp. 2-3; Za’ba, pp. 2-3.

44 Malays in Malaya, p. 1.

45 Ibid.; Sejarah ringkas Tanah Melayu, pp. 2-3. 
The striking similarities in the often degrading and condescending treatment of Orang Asli in these histories and in those written by British writers force us to question why this was the case. It may be easy to assume that the authors had taken many elements from British authors on the subject, and that this distaste was yet another aspect to these borrowings. However, if we shift the focus away from the British to take into consideration the history of interaction between Malays and Orang Asli and ask why else Malay authors might want to promote such a stance against indigenous groups, a few other explanations arise which point to a different impetus behind such a race discourse. Contrary to seeing Malays and Orang Asli as one in their indigenous status, the Malay intelligentsia saw indigenous peoples as primitive and belonging to an altogether different category. This perception stems from earlier views on indigenous peoples based on debt-bondage relationships between the two broad groups. Kirk Endicott has outlined the history of Malay domination over indigenous groups, a history which is related to the negative stereotypes Malays have of these groups. The position of Orang Asli as non-Muslims and closer to nature due to their way of living, seen as primitive by Malays, placed them outside of the cultural codes which governed interactions between people. ${ }^{46}$ Furthermore, the privileged position of Malays taken on from the anthropological field, which treated them as a people separate from, and better than, other groups in Malaya, also served to deprive Orang Asli of autonomy in their dealings with Malays and put them out of the running for the right to govern the peninsula at least in their own affairs, again positioning Malays as the only true heirs to governance.

At the same time, not only did the Malay intelligentsia adopt the anthropological knowledge to different ends, Malays in general were pivotal in crafting the knowledge itself from the beginning. The coincidence between strands of thinking makes sense if it is kept in mind that British anthropologists relied heavily on Malay help and knowledge in order to study Orang Asli. This may be seen in instances where Malays were used to gain access to some of these groups who were living in remote areas. The names of specific groups were also taken from names used by Malays. ${ }^{47}$ The British anthropological concept of Malays as separate from Orang Asli may be said to emanate from Malay and Orang Asli informants' own insistence on their differentiation. This is despite the fact that there were numerous documented cases of Malays and Orang Asli changing categories through shifting lifestyles and through intermarriage. In an entertaining account of a man who identified himself as Malay but whose maternal great-grandfather was Orang Asli, he described changing from being Malay to being Orang Asli and back again depending on what the British required of him in his role as police officer. ${ }^{48}$ These factors make it difficult to ascertain exactly who was racially Malay or Orang Asli without taking into account living habits such as dress,

46 Kirk Endicott, 'The effects of slave raiding on the aborigines of the Malay Peninsula', in Slavery, bondage, and dependency in Southeast Asia, ed. Anthony Reid with the assistance of Jennifer Brewster (New York: St. Martin's Press, 1983), pp. 221-2.

47 Annandale and Robinson, Fasciculi Malayenses, pp. 8, 20, 23, 28.

48 Nor Nalla, A yellow sleuth (London: Hutchinson \& Co Ltd, 1931), pp. 12, 13, 48; T.R. Hubback, Three months in Pahang in search of big game: A reminiscence of Malaya (Singapore: Kelly and Walsh, 1907), p. 38; G.B. Cerruti, My friends the savages (Como, Italy: Cooperativa Comense, 1908), p. 102. 
food consumption and religion at a particular point in time. Malay informants would insist that Orang Asli were lower civilisationally when talking to British anthropologists, a feeling which was in turn reflected in the latter's scholarly writings though they disapproved outwardly of the Malays' characterisation. ${ }^{49}$

We find again a situation where the impetus for certain racial knowledge differs between the Malay intelligentsia and British authors. For many British anthropologists and colonial scholar-administrators, the creation of knowledge surrounding indigenous peoples was based on efforts to catalogue and organise people, and more importantly, to give legitimacy to a colonial government in Malaya to claim unused jungle area for land development. For Malays, however, the more recent dominant relationship between ruling elites and forest gatherers such as the Orang Asli meant that the latter were regarded as different from Malays though both were considered native. The similarities between what was written by the three Malay authors the views of anthropologists and scholar-administrators have to be understood in terms of the long interaction between Malays and indigenous groups and of the authors' position as Malays in a situation where they were seen to be under threat in an immigrant-swamped setting.

The final element of the three histories that will be used to illustrate a break with British race knowledge is the connections made between race and nation, and the ways in which the race was presented so that it would have enough currency to be seen as a nation. The rhetoric surrounding race and nation is ambiguous in the English language, with the terms sometimes conflating and sometimes diverging from one another depending on the contexts in which they were used. Whereas in the nineteenth century it was not unusual to call Malaya a 'nation' as Raffles did, by the 1920 s this became increasingly rare. ${ }^{50}$ The more common lens of interpretation for Malays was race. Margaretta Morris, an American scientist, wrote in 1906 that the framework of race was 'the typical thought of the second quarter of the nineteenth century' for many Western scholars. Even in her article written in the early twentieth century, she primarily used 'race' to refer to peoples in the Malay Archipelago. These groups were called 'nations' only when she relied on sources such as Raffles and Crawfurd who specifically used that term. ${ }^{51}$ In another instance, Hugh Clifford, a colonial official, provided some friendly advice in a letter addressed to Americans who had recently colonised the Philippines in 1899. He saw both Britain and America as 'nations' along with the Dutch, as the 'white races' governing the 'brown race' in Malaya and the Philippines respectively. ${ }^{52}$ Swettenham in 1907 still referred to many 'nationalities' in the ports of the West Coast of Malaya and deemed that the Malay women wore the 'national garment'. ${ }^{53}$ Yet the shift to race was even seen in the purposeful changing of census classifications from 'nationality' to 'race',

49 Annandale and Robinson, for instance, note that Malays characterise some indigenous tribes as 'beasts'. Though they do not use such a term to describe these groups throughout their work, they take for granted that the latter are savage and uncivilised (Annandale and Robinson, Fasciculi Malayenses, p. 6).

50 Raffles, Memoir of the life and public services of Sir Thomas Stanford Raffles, p. 15.

51 Margaretta Morris, 'Race and custom in the Malay archipelago', Journal of the American Oriental Society, 27 (1906): 196, 204.

52 Hugh Clifford, 'A lesson from the Malay states', The Atlantic Monthly, 84, 505 (Nov. 1899): 587-9.

53 Swettenham, British Malaya, pp. 9, 150. 
as the author of the 1901 census explained that the latter, though overlapping with the former, was more far-reaching and clear-cut. ${ }^{54}$

The shift to calling 'Malay' a race coincided with the rise in importance of the designation of nation. In the 1920s specifically, 'nation' had connotations of selfgovernment, rights and independence. To call a group of a people a nation would position them for a trajectory as a separate state if they were under colonial rule, whereas to assert that there was a 'race' and not a 'nation' in some instances would be to downplay the status of that group as undeserving of self-government. This was certainly the case with Malays in Malaya, with the rhetoric of 'a nation of Malays' used in the 1800s by Raffles being replaced with that of merely a race that was never unified in nationhood as British colonial power over Malaya was extended. ${ }^{55}$

The various ways in which the concept of a Malay race was used in the histories were analogous to the use of nation in the 1920s by Western authors who wrote about possible independence for colonised countries such as Wheeler and Rupert Emerson, thereby expanding the conceptual use of race. ${ }^{56}$ There was a focus on a people which was said to be of common racial origins, cultural habits or history. That cohesive group was in turn linked to a place and to a history of political involvement in the areas where they were found. Connotations of priority and privilege were associated with the group, along with their indigenous status. Indeed, in an article published in the Malay Mail in 1923, Za'ba used terms in English such as 'nation' and 'people' to describe the Malays. ${ }^{57}$ The comparison between Za'ba's Malay and English terminology with reference to the community of Malays suggests that there were affinities between his use of 'bangsa' and 'orang' and 'nation'. However, there were key differences between the two. Though 'race' in the Malay histories was expanded to include some aspects of 'nation', the concepts were not used in such a way as to try to oust the British from the peninsula, even though the English term was associated with decolonisation, self-government and independence. Indeed, the British did not appear to be the main concern of these authors. Rather, references to Malays were used in the histories as a way to entrench the authors in Malaya and to argue for certain rights against other groups under the umbrella of British power in the peninsula.

The elevation of Malays from a race category to that of a nation, which also entitled them to more rights, is most blatantly seen in Abdul Majid's The Malays in Malaya, by one of them. The medium of English and the extensive use of political vocabulary in his text set it apart from former histories. He wrote in English to reach a specifically English-speaking audience. With the groundwork laid in a similar fashion

54 Charles Hirschman, 'The meaning and measurement of ethnicity in Malaysia: An analysis of census classifications', Journal of Asian Studies, 46, 3 (Aug. 1987): 561.

55 Raffles, Memoir of the life and public services of Sir Thomas Stanford Raffles, p. 15; W.E. Maxwell, 'The Malay Peninsula: Its resources and prospects', in Honourable intentions: Talks on the British empire in South-east Asia delivered at the Royal Colonial Institute 1874-1928, ed. Paul H. Kratoska (Singapore: Oxford University Press, 1983), p. 128; Leonard Wray, 'Settlements on the straits of Malacca', in the same volume, p. 22.

56 Rupert Emerson, 'Introduction', in Institute of Pacific Relations Inquiry Series, Government and nationalism in Southeast Asia (New York: Institute of Pacific Relations, 1942), pp. 3-91; Wheeler, The modern Malaya.

57 Quoted in Hooker, Writing a new society, p. 70. 
to Za'ba's work, where a Malay race was presented as a mixture of peoples from the archipelago who were conjectured as having originated from either mainland Southeast Asia or Sumatra, he built on this racial history by shifting it to that of a nation in the present. In fact, he rewrote the history of Malaya and Malays as a history of a nation and used twentieth-century political terms such as 'sovereignty', 'suzerainty', 'citizens', 'colonization' and 'rights'. The 'Malay nation' was presented in the work as a nation among nations, albeit a small one. ${ }^{58}$ This raced nation, based on a population purportedly sharing similar racial characteristics, was used to bring up the issue of rights of Malays in Malaya, as well as the appropriateness of participation in government by groups other than Malays such as Chinese and Indians. Again there is a divergence from the race discourse of Malays in Malaya, with race being applied to a different end. 59

Unlike other tracts which evoked the nation as a form of anti-colonialism, Abdul Majid did not use nation and its accompanying connotations to argue for a British withdrawal from Malaya, even though he did call attention to the possible illegitimate nature of British power there. A more immediate menace was that of the Chinese in Malaya, the main threat to Malays. The cause for such concern, besides the image of the 'yellow peril' retarding Malays economically and politically, was the fear that Chinese as well as Indians had begun asking for rights to join the Malayan Civil Service. ${ }^{60}$ Abdul Majid explained that Malays let the British run their country in order to prevent an 'Asiatic nation' from taking over. ${ }^{61}$

Seeing Chinese and Indians rather than the British as the main threat to Malays, was by no means unusual. In an exchange between Za'ba and another prominent Malay intellectual, Syed Sheik al-Hady, published in the newspaper Al-Ikhwan in 1926, both men agreed that the British should not be made the target of criticism at a time when the more pressing danger was Chinese and Hindu Indians. Za'ba, however, still indicated that he felt the British played a role in oppressing Malays, while al-Hady specifically said that they were not the ones he saw as responsible for keeping Malays in a low position. ${ }^{62}$ Regardless of the reasons for such a position, the movement of the concept of Malays from race to nation, and the limitations placed on the vehicle of the 'Malay nation' do not necessarily include independence, pointing to divergences from general trends in British scholarship of Malaya and anti-colonial literature.

\section{Conclusion}

The discussion has focused on the three histories, and certain themes have been analysed. The first is the centrality of Malays in a racial history of Malaya, the second is the place of Orang Asli in their race rhetoric, and the last is the elevation of a Malay race to the status of nation. The racialisation of peoples, sultanates and histories in Malaya, considered to be the result of early British scholarship of the region, is turned

58 The Malays in Malaya, preface, pp. 29, 44.

59 Ibid., pp. 29, 31, 35.

60 Ibid., pp. 34-8, 103-4.

61 Ibid., pp. 90-4.

62 'Teguran dan jawaban-nya' in Al-Ikhwan, 16 Nov. 1926, in The real cry of Syed Shaykh al-Hady, with selections of his writings by his son Syed Alwi Al-Hady, ed. Alijah Gordon (Kuala Lumpur: Malaysian Sociological Research Institute, 1999), pp. 189-94. 
on its head in a move which may be seen as predictable in hindsight, but is novel in that the writing of a history of a race and linking that race to a place in itself gives entitlement. While the details on the whole remain the same, the difference in tone and selection between British authors presenting the material and Malay authors doing the same is palpable. The history of a colonised race is turned into a history of an indigenous race at a time where self-determination of a group of people is seen as legitimate. ${ }^{63}$

In the second instance, the overlap between British and Malay authors in their treatment of the subject of Orang Asli is evident in the use of similar names and divisions of groups, as well as shared perception of the place of Orang Asli as lower in the civilisational scale compared to Malays and indeed to most other races. A divergence in this race discourse arises, however, if a separate position of Malays is assumed as compared to the British, which brings to the fore a separate history of interaction between Malays and Orang Asli. The trajectory forward of positioning Orang Asli as primitive can be read as a continuation of this earlier history and as a new impetus to place Malays as the 'more worthy and civilised native' even though Malays and British alike agree that Orang Asli were 'there first'. In this case, the issue of complicities of knowledge between British and Malay writers can be seen as arising from parallel interests: while these Malay writers wanted to see themselves and not the Orang Asli as the heir of governance, British marginalisation of Orang Asli stemmed from wanting to claim that forest land inhabited by them was undeveloped and uninhabited. Finally, the conceptual power of race was expanded to include aspects of nation as it was used by Western scholars of the time. However, even that expansion was selective, with some Malay writers choosing to ignore anti-British sentiments in order to focus on what was regarded as a more immediate threat in the contest for access to governance through the civil service.

As for the question of the agency possessed by those operating in a colonial environment, the production of the histories, as well as writings in other areas, mark instances where a Malay-identified community took matters into their own hands. The activity generated by this community in the print arena calls into question the characterisation of Malays as remarkably apolitical and apathetic until the mid-1900s. ${ }^{64}$ Implicit in these characterisations is the higher value placed upon more overt modes of anti-colonialism and resistance, a more 'active' activism against the coloniser, as well as the expectation that there was no overlap of interests between certain segments of the colonised and coloniser, or that Malay newspapers were not seen as possible source material for things happening at this time, thereby excluding a very prominent voice in the writing of those histories. That there was agency within these writings is evident in the crafting of these histories and from looking at the product from the point of view of issues that were important to Malays as explicated in other writings.

What do the similarities and divergences between Malay and British writings on race say about race as colonial knowledge? The use of various elements of race

63 See, for example, the tone of Woodrow Wilson's speech given in 1918 on self-determination in The human rights reader: Major political writings, essays, speeches, and documents from the bible to the present, ed. Micheline R. Ishay (London: Routledge, 1997), pp. 299-304.

64 Roff, Origins of Malay nationalism, p. 150; Harry Miller, The story of Malaysia (London: Faber and Faber, 1965), p. 167. 
knowledge found in both spheres of writings in subsequent debates on race and in the present-day prompt a rethinking of the origins of race knowledge as something which is not only a hand-me-down from the British colonial period. Various colonised people theorised about race, significantly contributed to the terms of the discussion and impacted the ways in which the people of modern-day Malaysia talk about race.

The goal of this article has been to expand the scope of the colonial. It is a more forward-looking project that has aimed to trace how present day post-colonial countries in Southeast Asia strategically use certain tropes that have come to be assumed as originating from the colonial West while simultaneously condemning those former colonisers. These two impulses are anything but contradictory or mutually exclusive. The notion of 'complicities' can be used to understand the operation of this knowledge in these two circumstances. Showing the complicities of both parties in the production of this knowledge does not in any way excuse former colonisers and the effects of colonialism. Rather, the purpose of detailing the overlap of ideas between coloniser and colonised is to point out their shared bases of knowledge and to rethink the interaction of the non-uniform colonised with colonial knowledge. In the case of Malaya, and using these authors and their works, race can be seen as a concept common to both intellectual groups. Malay and British genealogies that lead back not only to Europe but more importantly to situations in the Malay Archipelago can be written in attempts to think of race in the broader colonial setting. 